\title{
The Relationship Of Physical Activity With Body Mass Index Clients With Coronary Heart Disease In Heart Polyclinic Of Ulin General Hospital Banjarmasin
}

\author{
Yiyin M.A.Elkenas ${ }^{1 *}$ \\ ${ }^{1}$ Department of Science Nursing, STIKES Sari Mulia, Banjarmasin Indonesia \\ *yiyinelkenans1@gmail.com \\ Jami Hariyadi Saputra ${ }^{1}$ \\ ${ }^{1}$ Department of Science Nursing, STIKES Sari Mulia, Banjarmasin Indonesia \\ Jamihs732@gmail.com \\ Jhody Akhmad Irfansyah ${ }^{1}$ \\ ${ }^{1}$ Department of Science Nursing, STIKES Sari Mulia, Banjarmasin Indonesia \\ jhodyai@gmail.com
}

\begin{abstract}
Objective: To Analyze the relationship of physical activity with a BMI in the client with coronary heart disease.

Method: Quantitative research with cross sectional approach. The study population was a client with Coronary Heart Disease in the Policlinic of the Ulin General Hospital Banjarmasin with the number of 202 people. The number of samples are 57. The sampling technique used purposive sampling. The collecting data using questionnaires weight and height measurement. Analysis with correlation of Gamma \& Somer's.

Results: When physical activity is done regularly it will avoid overweight clients with coronary heart disease to reduce the risk of complications in clients with coronary heart disease with a value of $p=0.008<0.05$ then there is a significant correlation between physical activity with BMI levels with moderate correlation (0.551).

Conclusions: Physical activity is linked to the incidence of overweight in clients with coronary heart disease at the Polyclinic Hospital Ulin Banjarmasin.
\end{abstract}

Keyword: Physical Activity, Body Mass Index, Coronary Heart Disease

\section{INTRODUCTION}

Coronary Heart Disease is not necessarily between the need for oxygen supply and cardiac muscle, with the provision that is given by the coronary arteries [1]

According to World Health Organization (WHO) Estimation (2012), Coronary Heart Disease mortality rate in the world as much as 7.4 million, until 2030 estimated the death rate due to CHD will continue to rise to reach 23.3 million worldwide.[2]

Research from AHA (2011) which discuss about secondary prevention on client with Coronary Heart Disease said all clients with Coronary Heart Disease recommended to do physical activity for 30 minutes to 60 minutes with moderate intensity for 7 times a week and at least 5 times a week recommended physical activities such as walking in the workplace, gardening and doing 
housework that aims to increase the heart's capacity and to maintain the client's body fitness with Coronary Heart Disease.[3]

In 2004 coronary heart disease caused 921,000 deaths and constituted $45 \%$ of deaths in the country, after in the United States about 478,000 people die of Coronary Heart Disease, 1.5 million people had a heart attack, 407,000 people in Europe reaching 20,000-40,000 people from 1 million inhabitants and in the UK Coronary Heart Disease has caused more than 180,000 deaths every year. The study conducted by Jikei in Japan in 2006 was obtained from 3,081 clients, recorded $41 \%$ who suffered from coronary heart disease. [4]

In 2013 Banjarmasin ranks 12th out of 33 provinces in Indonesia with Coronary Heart Disease. Data of RSUD Ulin Banjarmasin recorded 520 cases of Coronary Heart Disease during 2011. While in 2012 reached 830 cases, so the year of heart disease is increasing [5]

Preliminary study conducted on 25 november 2015 in obtaining secondary data from 2013 clients with Coronary Heart Disease as many as 432 clients with the classification of Coronary Heart Disease Unstable angina as 120 clients and ST-ACE Inflammatory Acute Infarction (STEMI) as 128 clients and clients with Non-Acute Myocardial Elevation (NSTEMI) as 184 clients. In the Year 2014 clients with Coronary Heart Disease as many as 523 clients with the classification of Coronary Heart Disease Unstable angina as many as 147 clients and STEMI as many as 132 clients and clients with NSTEMI as much as 228 clients and data in 2015 clients with Coronary Heart Disease experienced increase per year with totaly PJK 698 clients with the classification of Coronary Heart Disease Unstable angina as 188 clients and STEMI as 269 clients and clients with NSTEMI as 241 clients. Withdrawn data from August to November 2015 there are 202 clients with Coronary Heart Disease which is $50 \%$ client characteristics are female and $50 \%$ are male.

\section{RESEARCH METHODS}

The research was conducted at Polyclinic of Ulin general Hospital Banjarmasin with target is client with Coronary Heart Disease. Research have done in February 2016. The target sample used was clients with Coronary Heart Disease at the Heart Polyclinic with a total of 57 respondents. The sampling technique used purposive sampling where the sample must match the inclusion and exclusion criteria found by the researcher.

This study used correlational research method, is research that aims to reveal the relationship between 
independent variables and dependent variables [6]

In the study used cross sectional design, is research used in research that aims to determine the relationship between Physical Activity with Body Mass Index.

This research uses primary data collection method, in this study using a questionnaire directly distributed to clients of Coronary Heart Disease, on physical activity and use measuring instruments in the form of scales and meters to measure height then in accumulated to get Body mass Index value.

In this study using nonstandardized questionnaire research instruments that have been tested for validity and reliability of 30 people on clients with Coronary Heart Disease in the Internal Medicine clinic Hospital H.Moch. Ansari Saleh Banjarmasin.

In this study used two types of data analysis. The first analysis is univariate analysis and for the second data analysis using bivariate data analysis using Gamma technique and Somer.

\section{RESULT}

Characteristics of Respondents

Table 1. Age Characteristics Respondents

\begin{tabular}{llcc}
\hline No & Age & F & $\%$ \\
\hline 1 & $25-34$ & 16 & $28 \%$ \\
\hline 2 & $35-44$ & 11 & $19,2 \%$ \\
\hline 3 & $45-54$ & 20 & $35 \%$ \\
\hline 4 & $55-64$ & 5 & $8,7 \%$ \\
\hline 5 & $65-74$ & 2 & $3,5 \%$ \\
\hline & Totsly & 57 & $100 \%$ \\
\hline
\end{tabular}

Based on the above table the highest percentage is the age between 45 to 54 years, ie as many as 20 people $(35 \%)$.

Table 2. Job characteristics

\begin{tabular}{llll}
\multicolumn{4}{c}{ Respondents. } \\
\hline No & Job & F & $\%$ \\
\hline 1 & Housewife & 19 & $33,3 \%$ \\
\hline 2 & Private & 28 & $49,2 \%$ \\
\hline 3 & Employee & 10 & $17,5 \%$ \\
\hline & Totaly & 57 & $100 \%$
\end{tabular}

Based on the Table above, the highest percentage is private as 28 people $(49.2 \%)$.

Table 3. Educational Characteristics

\begin{tabular}{|c|c|c|c|}
\hline \multicolumn{4}{|c|}{ Respondents } \\
\hline No & $\begin{array}{l}\text { Educatiaon } \\
\text { level }\end{array}$ & $\mathrm{F}$ & $\%$ \\
\hline 1 & $\begin{array}{l}\text { Primary } \\
\text { school }\end{array}$ & 8 & $14 \%$ \\
\hline 2 & $\begin{array}{l}\text { Junior high } \\
\text { school }\end{array}$ & 17 & $29,8 \%$ \\
\hline 3 & $\begin{array}{ll}\text { Senior High } \\
\text { School }\end{array}$ & 22 & $38,5 \%$ \\
\hline 4 & Bachelor & 10 & $17,5 \%$ \\
\hline & Totaly & 57 & $100 \%$ \\
\hline
\end{tabular}

Based on the table that had the highest percentage is the respondents who Senior high school that is as 22 people $(38.5 \%)$.

Table 4. Gender Characteristics Respondents

\begin{tabular}{llll}
\hline No & Gender & F & $\%$ \\
\hline 1 & Male & 25 & $43,9 \%$ \\
\hline 2 & Pemale & 32 & $56,1 \%$ \\
\hline & Totaly & 57 & $100 \%$ \\
\hline
\end{tabular}

Table 5. Analysis of physical activity

\begin{tabular}{llll}
\hline No & Category & F & $\%$ \\
\hline 1 & Easy & 6 & $10,5 \%$ \\
\hline 2 & Medium & 30 & $52,7 \%$ \\
\hline 3 & Heavy & 21 & $36,8 \%$ \\
\hline & Totaly & 57 & $100 \%$
\end{tabular}


Based on the above table of respondents who have light physical activity with the number of 6 people (10.5\%), Medium physical activity with the amount of 30 people $(52,7 \%)$ while amount of client with heavy physical activity counted 21 people $(36,8 \%)$.

Table 6. Analysis of Body Mass Index

\begin{tabular}{llll}
\hline No & Category & F & $\%$ \\
\hline 1 & No Excess Weight & 22 & $38,6 \%$ \\
\hline 2 & Overweight & 26 & $45,6 \%$ \\
\hline 3 & Obesity & 9 & $15,8 \%$ \\
\hline & Totaly & 57 & $100 \%$ \\
\hline
\end{tabular}

Based on the table shows that most of the respondents have Body Mass Index value with the category not overweight amounted to 22 people (38.6\%) \%) while the value of Body Mass Index with the category of overweight amounted to 26 people (45.6\%) and the value of Body Mass Index with the category of obesity amounted to 9 people (15.8\%).

\section{BIVARIATE ANALYSIS}

Table 7. Physical Activity Relation Analysis With Body Mass Index In Clients With Coronary Heart Disease Using Gamma Correlation Test And Somers'

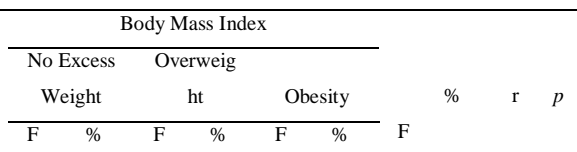

\begin{tabular}{|c|c|c|c|c|c|c|c|c|c|c|c|}
\hline Phy & Heavy & 1 & $\overline{52,4}$ & 8 & 38,1 & 2 & $\begin{array}{l}9,5 \\
\end{array}$ & 2 & 10 & \multirow[b]{3}{*}{0} & \\
\hline sica & & 1 & $\%$ & & $\%$ & & $\%$ & 1 & $0 \%$ & & \\
\hline 1 & Mediu & 1 & 36,7 & 1 & $60 \%$ & 1 & 3,3 & 3 & 10 & & 0 \\
\hline \multirow{3}{*}{$\begin{array}{l}\text { Act } \\
\text { vity }\end{array}$} & $\mathrm{m}$ & 1 & $\%$ & 8 & & & $\%$ & 0 & $0 \%$ & \multirow{2}{*}{$\begin{array}{l}, \\
5\end{array}$} & , \\
\hline & \multirow[t]{2}{*}{ Easy } & \multirow[t]{2}{*}{0} & \multirow[t]{2}{*}{$0 \%$} & \multirow[t]{2}{*}{0} & \multirow[t]{2}{*}{$0 \%$} & \multirow[t]{2}{*}{6} & 100 & 6 & 10 & & 0 \\
\hline & & & & & & & $\%$ & & $0 \%$ & \multirow{3}{*}{$\begin{array}{l}5 \\
1\end{array}$} & 0 \\
\hline & & 2 & 38,6 & 2 & 45,6 & 9 & 15,8 & 5 & 10 & & 8 \\
\hline & & 2 & $\%$ & 6 & $\%$ & & $\%$ & 7 & $0 \%$ & & \\
\hline
\end{tabular}

Based to result of analysis, pvalue $p=0,008<0,05$, it can be concluded that the correlation between Physical Activity and Body Mass Index is significant. It can be deduced from the value of $r=0.551$ which means the positive direction and the level of correlation is.

Positive direction indicates that the more physical activity the smaller the happening of excess body weight which can cause complication in client with coronary heart disease at Polyclinic of Ulin Banjarmasin General Hospital.

\section{DISCUSSION}

1. Physical Activity In Clients With Coronary Heart Disease At Heart Polyclinic of ULIN General Hospital Banjarmasin.

In research conducted by researchers in clients with coronary heart disease in Polyclinic Ulin General Hospital Banjarmasin found that physical activity is done and the amount of respondents as 57 people. So the result of the category of easy physical activity on clients with Coronary Heart Disease as 6 people $(10.5 \%)$, on the medium activity in clients with coronary heart disease as 30 people $(52.7 \%)$, and with heavy activity in clients with Coronary Heart Disease found as 21 people $(36.8 \%)$, the highest percentage of physical activity category in the respondents were medium physical activity that was 30 people $(52,7 \%)$. Take a look at from the results that there are several 
factors that affect the level of physical activity of respondents at the clinic Ulin General Hospital Banjarmasin age and lifestyle, resulting in excess energy. Various conveniences of life also lead to reduced physical activity, as well as technological advances in various areas of life to encourage people to take a life that does not require heavy physical work [6]

2. Body Mass Index In Clients With Coronary Heart Disease at Polyclinic Heart general Hospital ULIN Banjarmasin.

In research conducted by researchers on clients with coronary heart disease at Polyclinic Ulin General Banjarmasin Hospital found that the Body Mass Index with the amount of respondents as 57 peopleSo get the Body Mass Index category is not overweight on clients with coronary heart disease as 22 people $(38.6 \%)$, excess weight in clients with Coronary Heart Disease as 26 people (45.6\%), and obesity in clients with Coronary Heart Disease found as 9 people $(15.8 \%)$. The highest percentage of Body Mass Index on the respondents was overweight as 26 people (45.6\%). This is supported by the theory of Abid 2014 which says the value of Body Mass Index is a parameter that can be used to measure fat content and assess the level of obesity and research that has been done by Lemieux $\mathrm{L}$ et al Body Mass Index associated with increased levels of cholesterol and triglycerides, lower HDL cholesterol levels and increase levels of LDL cholesterol that can cause Coronary Heart Disease.[7,8]

3. Relationship of physical activity with Body Mass index In Clients With Coronary Heart Disease In Heart Polyclinic of ULIN General Hospital Banjarmasin

In the research obtained the results of the correlation test of gamma and somers in table 4.9 obtained $\mathrm{p}$ value $=$ $0.008<0.05$, it can be concluded that the correlation between Physical Activity with Body Index is meaningful. It can be deduced from the value of $r=0.551$ which means a positive direction with a moderate level of correlation, which shows that the more severe the physical activity will be the less the occurrence of excess body weight that can cause complications in clients with coronary heart disease in Polyclinic Ulin General Hospital Banjarmasin.

In the research, it was found that those who did heavy physical activity who did not experience overweight were 11 people $(52,4 \%)$, who performed heavy physical activity who were overweight as 8 people (38.1\%), and who do heavy physical activity who are obese as 2 people (9.5\%). So it can be concluded that if the physical activity is done more severe then 
it can reduce the risk for excess weight in clients with coronary heart disease in Polyclinic ULIN General Hospital Banjarmasin. Therefore it is necessary information about the need for the benefits of routine physical activity in doing as recommended by medical personnel to avoid overweight and complications of Coronary Heart Disease. According to researchers at the American Heart Association's (AHA) control and prevention center, found that regular physical activity can prevent illness and improve health because physical activity can strengthen the heart and blood vessels because active muscles require more oxygen and fuel.. The theory is also supported by research from Sattlemair, et al (2011) and Sofi, et al (2007) which says simply by doing activities such as doing daily activities and exercising can improve the work and heart function, lung and blood vessels, increase muscle strength and bone density, and increase body metabolism to prevent obesity and maintain ideal body weight so as to reduce the risk of coronary heart disease $[9,10]$.

\section{CONCLUSION}

Physical activity is linked to the incidence of overweight in clients with coronary heart disease at the Polyclinic Ulin General Hospital Banjarmasin.

\section{REFERENCES}

[1] Mila C et al. (2010). Therapeutical Strategies in Mild Cognitive Impairment. Pubmed Vol 40 NO 45

[2] Abidin, Z. (2008) Faktor Risiko Penyakit Jantung Koroner (PJK) pada klien rawat inap di Cardiovascular Care Unit (CVCU) Cardiac Center RSUP DR. Wahidin Sudirohusodo Makassar. Unnes Journal of Public Health. Vol 13. No. 26

[3] American Heart Association (AHA). (2011). Secondary Prevention and Risk Reduction Therapy for Patients with Coronary and Other Atherosclerotic Vascular Disease. CrossMark. Vol 67 No 10: 844-848

[4] Mathers, C. \& Loncar,D. (2006). Projections of Global Mortality and Burden of Disease from 2002 to 2030. ResearchGate Vol 31 No.110

[5] Dinas Kesehatan, (2012). Dinas kesehatan Provinsi Kalimantan. Available from: http://www.depkes.go.id/resources/do wnload/profil/PROFIL_KES_PROVI NSI_2012/22_Profil_Kes.Prov.Kalim antanSelatan_2012.pdf

[6] Kemal (2015). Hubungan Aktifitas Fisik Dan Kejadian PJK Di Indonesia. Biomedikia. Vol 5 No. 16

[7] Abid R. (2014). Association of low physical activity with high body mass index in both genders. Biomed Central. Vol 6, No 3.

[8] Lemieux I, Pascot A, Couillard C.(2012). Hypertriglyceridemic waist a marker of atherogenic metabolic triad

(hyperinsulinemia,hyperapolipoprotei $\mathrm{n}$ B, small dense LDL) in men. Circulation; Vol 102 No 179 
[9] Sattelmair, J., Pertman, J., Ding, E. L., Kohl III, H. W., Haskell, W., Lee, I. M. (2011). Dose Response between Physical Activity and Risk of Coronary Heart Disease: A MetaAnalysis. Circulation. Vol 124 No 78

[10] Sofi F, Capalbo A, Cesari F, Abbate R, Gensini GF. (2008). Physical activity during leisure time and primary prevention of coronary heart disease: an updated meta-analysis of cohort studies. Circulation.Vol 247 No 27. 